\title{
Chemical Engineering and Operations Research: A Passing Flirtation or Marriage?
}

\author{
Marcel Joly ${ }^{1,2,3, *}$ and Jorge Andey Wilhelms Gut ${ }^{1}$ \\ 1Departamento de Engenharia Química da Escola Politécnica da Universidade de São Paulo \\ ${ }^{2}$ Centro de Tecnologia da Informação, Automação e Mobilidade (CIAM) do Instituto de Pesquisas \\ Tecnológicas do Estado de São Paulo (IPT) \\ ${ }^{3}$ Centro de Excelência em Tecnologia de Aplicação em Automação Industrial (Cetai) da Petrobras Petróleo \\ Brasileiro S.A \\ * Autor para correspondência: mjoly@utfpr.edu.br e mjoly@usp.br
}

\section{RESUMO}

Desde a década de 1980, a parceria tecnológica entre a Petrobras e a Universidade de São Paulo (USP) na área da automação industrial tem se revelado prolífica em via dupla. Contribuições científicas e tecnológicas relevantes têm sido continuamente produzidas no âmbito do domínio científico da Engenharia Química. Entre os mais recentes resultados desta fecunda parceria está a criação da disciplina Otimização Aplicada à Gestão de Operações da Indústria Química, a qual agora compõe o currículo do curso de graduação em Engenharia Química da Escola Politécnica da USP na modalidade de disciplina optativa oferecida no último período acadêmico. Baseada em um programa de capacitação tecnológica voltado ao ensino de fundamentos de Pesquisa Operacional (PO) a engenheiros de processamento da Petrobras dentro do ambiente industrial e em um curso de pós-graduação em PO, esta nova disciplina foi idealizada e estruturada com apoio do Centro de Excelência em Tecnologias de Aplicação em Automação Industrial (Cetai - Petrobras) e tem se revelado um sucesso inegável entre os estudantes de Engenharia Química da USP. A importância deste resultado - aprendizagem de PO em nível de graduação - é aqui discutida à luz do papel crucial que tecnologias de apoio à tomada de decisões assistida por computador possui atualmente para a operação integrada da indústria química. Mais importante ainda é o fato de que a capacitação em PO pode ser entendida como uma etapa prévia, porém valiosa, para alavancar o desenvolvimento de pesquisa interdisciplinar de fronteira no âmbito da Engenharia Química moderna.

Palavras-Chave: Complexidade; Emergentismo; Modelagem Matemática; Otimização; Biologia de Sistemas.

\begin{abstract}
Since the 1980's, the technological partnership between Petrobras and the University of São Paulo (USP) in the field of industrial automation has been prolific in double lane. Relevant scientific and technological contributions have continuously been produced within several related chemical engineering $(\mathrm{ChE})$ disciplines. Among the latest results from this fertile collaboration is the exciting discipline Optimization Applied to Operations Management in the Chemical Industry which now is part of the USP undergraduate course curriculum in ChE as an elective course in the last academic period. Derived from an educational program formulated inside the Petrobras' industrial environment devoted to teaching Operations Research (OR) foundations to process engineers and from a graduate course on process optimization, this new course was idealized and didactically supported by the Petrobras Centre of Excellence (Cetai) and has been an undeniable success among the ChE students at USP. The relevance of this result - OR learning at undergraduate level - is here discussed in the light of the crucial role that computer-aided decision-making technologies currently have to the integrated performance of the chemical industry. Most importantly, such OR learning should be understood as a former, yet essential step for ChE students to develop high-profile interdisciplinary research in the modern ChE science.
\end{abstract}

Keywords: Complexity; Emergentism; Mathematical Modeling; Optimization; Systems Biology.

\section{Prolegomenon}

If a clever chemical engineering student could place three wishes to a genie getting out from an Aladdin lamp, he/she would surely say:

\author{
"To learn Operations Research techniques; \\ To understand cellular and molecular biology; \\ To develop complex thinking."
}


In fact, and not surprisingly, Chemical Engineering $(\mathrm{ChE})^{1}$ is a scientific domain characterized by an enormous plasticity. Since exposed to a wide range of length scales and trained to think in terms of systems, chemical engineers are competitive candidates to take a leadership position in exciting, novel interdisciplinary developments (see OTTINO, 2003, 2011). In fact, augmentation of the curriculum and research reshaping have long been undeniable hallmarks of the discipline, whose adjacent possible (KAUFFMAN, 1996) is now touching a new kind of science guided by principles of the general systems theory (BERTALANFFY, 1968), or, in other words, by Philosophy (MOSSIO et al., 2009).

This is because Biology is currently central to the ChE scenario (Figure 1): rather than understanding the individual role of each building block of the system, the focus should now be on the power of the wholeness. Chemical engineers are moving from examining complicated systems (e.g., a mechanical engine) to analyzing complex systems (e.g., a living cell or organism), which display organization without any external organizing principle being applied (Figure 2). In contrast to complicated systems, in which a key failure in a critical part can lead the entire system to a halt, complex systems are characterized by adaptability and robustness. In such systems, emergent properties play a role.

Due (but not limited) to these reasons, this is an appropriate time to pause and to reexamine the ChE curricular landscape. Despite its mutant phenotype over time, the ChE science has a constant: the use of mathematical modeling. As any other branch of engineering, a primary goal of the ChE science is to predict the behavior of the system of interest by formulating testable hypotheses and guiding experimental design to maximize the information obtained. This depends on mathematical modeling. For this reason, ChE fundamentals (e.g., heat and mass transfer, unitary operations, etc.) should remain as the curricular backbone of ChE courses: once fundamentals are learnt, the

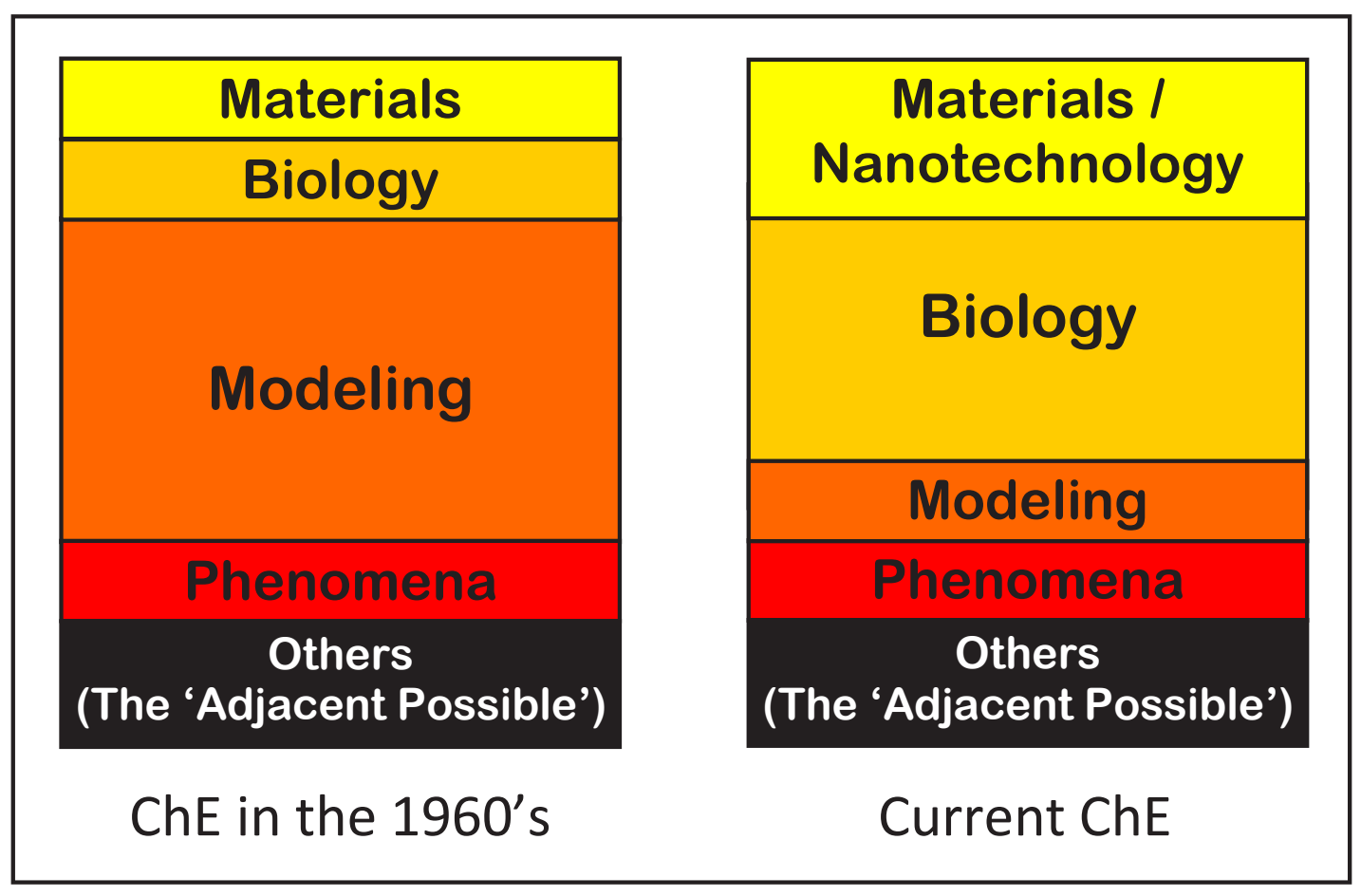

Figure 1 - The Chemical Engineering (ChE) domain revolution. The ChE domain switched from a mathematical core in the 1960's where bio and materials (as part of a whole "adjacent possible") were trying to get in to a complex reality where ChE is now faced with the organicist paradigm. For instance, the birth of ChE-derived departments (biomedical, bioengineering, etc.) is a natural outcome of such dynamic process (discussed in Ottino, 2005). 


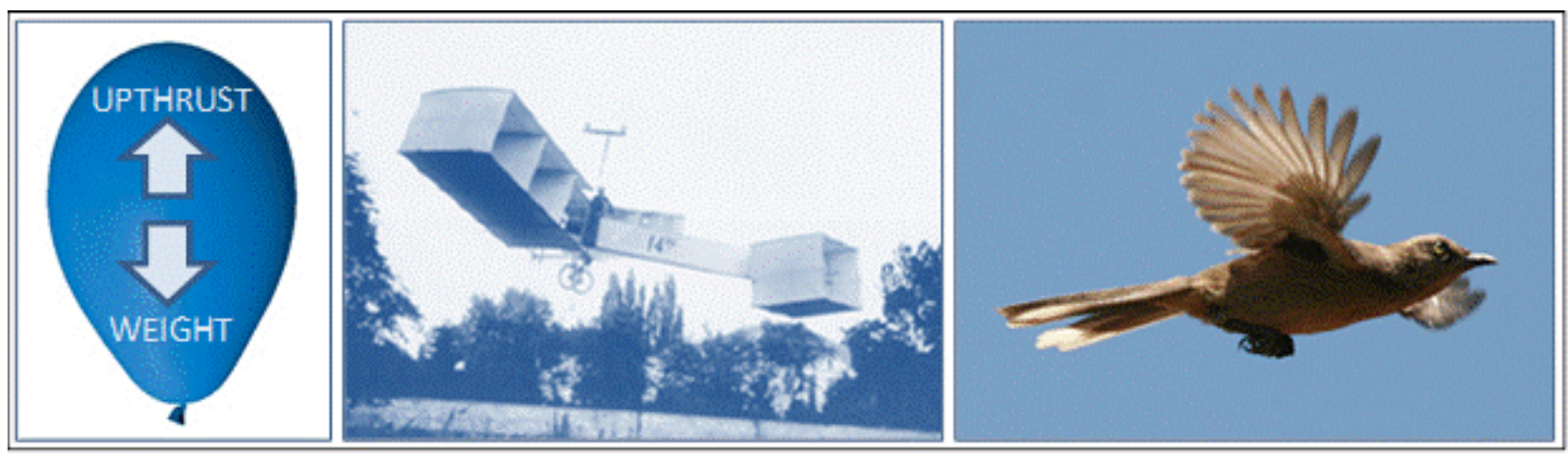

Figure 2 - Simple, complicated and complex (discussed in Ottino, 2003, 2011). (Left panel) A balloon may be considered an example of simple system; it is composed by a single part and has dynamics deterministically described by fundamental laws of physics. (Center) The precursor of modern airplanes, the 14-Bis was built by the Brazilian inventor Alberto Santos Dumont in 1906. Since composed by many parts, airplanes are typical examples of complicated systems. In these systems, a fabrication defect or operational failure in one critical component may result the collapse of the entire structure. Hence, redundancy is often considered by engineers when designing complicated systems. (Right) In sharp contrast, robustness and adaptation are the hallmarks of complex systems. The Sabiá-laranjeira (Turdus rufiventris), a national symbol of Brazil, is an example of a complex system. Since a habitué of the metropolitan region of São Paulo city ( 20 million people), this bird has adapted over the past decades to sing earlier and earlier at dawn, when the noise of the city is still low. Otherwise, the melody sung by male birds would be suppressed by the diurnal noise pollution and would not be heard by female birds, with potential implications for the specie birth-rate (Adapted from Joly, 2016).

ChE student is qualified to model. Yet modeling is just the first step of the journey...

Firstly, because a model needs to be solved. And models devoted to representing real-world systems in ChE will generally involve discrete - usually binary decisions (e.g., should a crude oil blend $\mathrm{X}$ be added to the feed of a crude distillation unit right after changing the unit operation mode? The answer will be "yes" or "no"). However, few, if any, ChE undergraduate courses in Brazil teach how to implement and to solve a discrete-continuous (decision-making) optimization model in an efficient manner, that is, by using a suitable technique and an appropriate platform.

Secondly, because models are mere caricatures of reality. As brightly noted by Oreskes and her coworkers, "a model, like a novel, may be convincing" (ORESKES et al., 1994). That is, the human factor will never be replaced by machines. In other words, any mathematical solution must be interpreted and this requires qualified human resources. In this sense, $\mathrm{ChE}$ undergraduate courses now have a crucial educational mission which is preventing "optimization" from becoming something much cited, but little studied and still less understood in the industrial environment. Whereas "optimization" remains at the top of the favorite vocabulary of many poseur managers, many of them ignore the most basic optimization concepts, such as marginal value.

Thirdly, because the solution of an optimization model - or more generally, an optimization application - needs to be implemented in real-world settings. Moreover, much care should be taken here in order to prevent the Herculean effort invested so far from becoming a Pyrrhic victory. Believe it or not, developing the optimization model may be the easier part of the work in some cases. Since optimization touches interests and the power of key people in key departments of the corporation, a finished computer-aided decision-making technology (the Operations Research - OR solution) should be introduced in the battlefront only after a carefully planning is done in consensus with all the participants involved in the process. In fact, and not by chance, psychology is another discipline which, we argue, should be seriously considered to be part of any modern ChE curriculum. For instance, the so called "Dunning-Kruger effect" - a cognitive bias 
in which relatively unskilled persons suffer illusory superiority, mistakenly assessing their ability to be much higher than it really is (KRUGER \& DUNNING, 1999) - may be cited as one of many threats which may be present in operational and administrative levels.

In this vein, ancient cultures and paradigms in ChE education are barriers that must be overcome. It is not uncommon to hear - even in the academic environment - that "operations research is a métier for production engineers, not for chemical engineers", which is an illusion. For instance, in the refineries of Petrobras, the state-own Brazilian multinational energy company, production engineers are not working with refinery production planning and scheduling activities. To understand such paradox one should consider that chemical plants in general, and oil refineries in particular, are very specialized production systems. They involve peculiar concepts and disciplines which can be alien to the standard curriculum of production engineering. Not only batch operations (e.g., crude oil receipt from long oil pipelines and product dispatch to customers), but also continuous processes (e.g., crude distillation units, in-line blending units, etc.) whose models deal with a "continuum" [i.e., information at the molecular level (HU et al., 2002)] that must be considered by refinery planners and schedulers. These processes are interconnected in a customized fashion depending on the refining scheme and supply-chain logistics (e.g., local customers may be supplied by running tanks and local (dedicated) pipelines). Furthermore, operational ("business") rules are (very) specific for each plant. Here, specialized knowledge regarding highly nonlinear dynamic processes (e.g., reactional units, such as fluid catalytic cracking units, hydrotreating units, etc.) and physico-chemical properties (e.g., petroleum products specifications, such as cetane number, octane number, pour point, freeze point, Reid vapor pressure, etc.) is merged with specialized know-how of plant automation. Industrial chemical processes are increasingly being controlled in real time by complex advanced control systems and real-time optimization systems whose optimization drive must be originated from the adjacent off-line optimization layer (production scheduling).

Therefore, having competent process engineers with wide experience in plant operation within the production planning and scheduling departments of oil refineries is mandatory. These professionals, which have a high-profile in the organization (discussed in ZHANG \& VALLEUR, 2010), must have open minds to test new solutions and to rethink work processes aiming at improving the economic performance of the plant. In this sense, the background in OR may act as a formidable catalyst to reach such lofty goal (Figure 3): given an existing trade-off between two or more variables impacting plant profitability, the optimization opportunity can only be properly identified and exploited by those who have competence to model the phenomenon and to interpret its mathematical solution. There is no margin to adventures in this field; plant safety is at stake.

"Necessity is the mother of invention" and the $\mathrm{ChE}$ community has corroborated with this dictum: after pioneering real-world (military) applications of OR in World War II, the first industrial application of OR techniques was inside a chemical company (e.g., SYMONDS, 1955). Since then, the successful marriage between $\mathrm{ChE}$ and $\mathrm{OR}$ has decisively contributed to the state-of-the-art of both; not by chance $\mathrm{ChE}$ departments have emerged as the main sites of OR developments over the past decades (e.g., Carnegie Mellon University with Ignacio E. Grossmann and others unintentionally left out).

\section{Development}

The chemical engineering course at University of São Paulo is organized as a cooperative course in which the students study basic science and engineering in the first four semesters. From the third to the fifth year of the course, it is structured as a sequence of nine periods of four months that can be either dedicated to academic courses or to internships in cooperation with companies. In the last academic period, the students have some elective courses to choose in order to get the required credits. The courses that are offered by the faculty vary each year based on the students demand. Some 


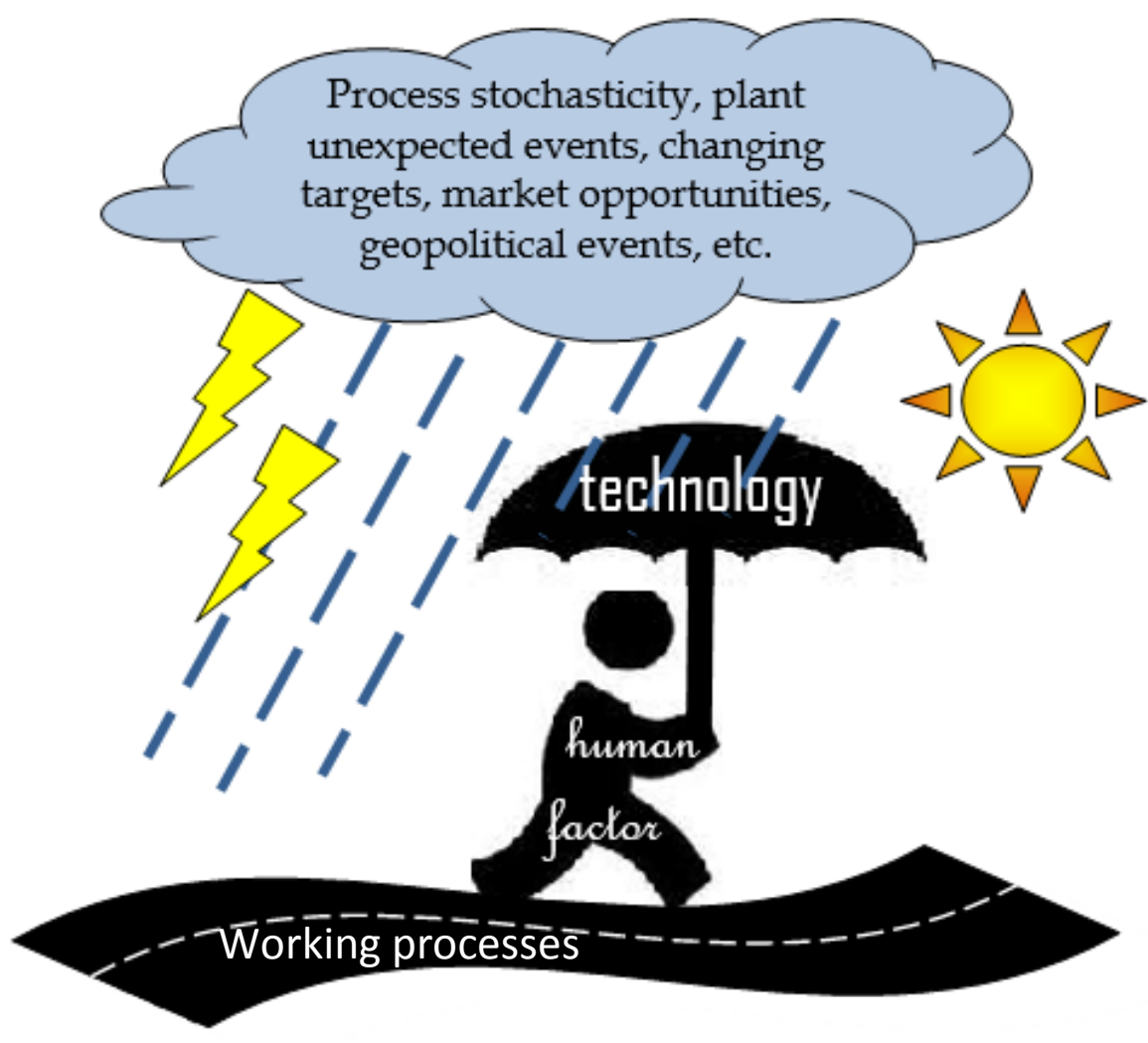

Figure 3 - Conceptual model to explain the role of working processes, the human factor and technology in the integrated performance of a chemical plant. Underscored by harmonic (i.e., integrated) working processes, qualified human resources - able to properly operate advanced computer-aided decision making tools - can overcome typical difficulties associated with endogenous and exogenous perturbations which are inherent to the industrial environment.

examples of courses are Analysis of Industrial Data, Biotechnological Processes, Engineering of Polymerization Reactions, Practice in Food Engineering, Green Process Synthesis or Advanced Computation for Chemical Process Studies.

Based on the aforementioned importance to integrate $\mathrm{OR}$ into the ChE curriculum, an undergraduate course was idealized by the authors based on a pioneer corporate-wide strategic learning program on OR techniques taught at Petrobras for chemical engineers working at the planning/scheduling department (Joly et al., 2015a) and on the graduate course Optimization of Chemical Process offered to master and doctorate students. This new course, entitled Optimization Applied to Industry Operations Management, was firstly taught in 2014 as one of the elective options to the students during the last academic period.

The course consisted of lectures, practical activities with tutoring and invited talks with engineers from Petrobras (total of $50 \mathrm{~h}$ ). The size of the class was limited to 25 students in order for the tutoring to be effective. The approach was to intercalate theory, practice and application for a more effective learning. The theoretical part of the course syllabus included optimization theory, optimization of unconstrained functions, linear programming, nonlinear programming, mixed-integer linear programming and mixed-integer nonlinear programming techniques. Chemical engineering optimization problems were modeled and solved by the students in tutoring classes using solution techniques and finished ORbased tools prototyped in professional modeling platforms, such as GAMS (ROSENTHAL, 2010). Tests, optimization case problems and exercise lists were used for evaluation and monitoring.

The problems modeled and solved by the students addressed typical engineering issues, such as minimization of transport costs, optimal design of a tank, optimal separation sequence, manufacture 
optimization, optimal blending, model fitting, chemical process optimization, travelling sales person problem or assigning problem. Moreover, at the end of the course, students were able to work on more complex problems with continuous and discrete variables such as the optimal facility location and distribution, optimal scheduling of a batch plant (MENDEZ et al., 2000) or the optimal design of a batch plant with multiple products (BIEGLER et al., 1997).

At the end of the academic period, an evaluation of the courses was performed and this new OR course received the most praises among the students, which suggested that it should be included in the curriculum as a regular course due to its important contribution to their professional qualification. Most importantly, since it aimed to foster the development of self-regulated, reflective learners, this novel undergraduate course technically enabled and motivated students to develop further specialization in OR applications.

Here traineeships ("scientific initiation") and final courseworks are included; have been directly supervised by the Petrobras Centre of Excellence for Applied Industrial Automation (Cetai). By interacting with refining business experts, these students solved hypothetical and (large-size) real-world OR problems associated with the operation of Petrobras refineries, thereby demonstrating the feasibility of successfully introducing a complex subject such as OR into de curriculum of $\mathrm{ChE}$ undergraduate courses. This is a crucial step to enable $\mathrm{ChE}$ students to develop front-edge research in novel, exciting subjects, such as systems biology (JOLY \& ODLOAK, 2013) and, hence, complex systems (JOLY \& RONDÓ, 2016).

Understanding $\mathrm{OR}$ as a value for the modern chemical engineer should be mirrored in the $\mathrm{ChE}$ undergraduate curriculum. Here, practical learning is an important strategy since it: (a) enables ChE to properly understand the relevance of OR to their formation, and (b) motivates initial scientific forays into de subject in undergraduate studies (e.g., JOLY et al., 2016). The introduction of OR disciplines at this educational stage has proven to be an important catalyst for motivating those students who have a vocation for research development to continue scientific investigation at graduate level. This step should ideally be preceded by the so called "Scientific Initiation" (SI) along which $\mathrm{ChE}$ undergraduate students fulfill a medium/long-term mentoring applying theory to practice. By considering a project-based learning strategy, the graduate student will, in general, devote her/his initial efforts to solving an industrial-size ChE engineering problem which is familiar to her/him (e.g., a chemical plant production planning/scheduling). This is important since understanding the "business rules" (the problem conceptual basis from which the mathematical model is derived) is immediate such that there is no need for understanding a new discipline (which is strongly desirable in a $\mathrm{PhD}$ program) before solving the problem itself.

At this initial phase of her/his scientific life (e.g., a M.Sc. program) - the ChE graduate student should give priority to learning mathematical modeling and algorithm techniques since this will enable the student to have the required in silico experience to overcome more complex interdisciplinary challenges ahead (e.g., a Ph.D. program). As far as possible, M.Sc. programs should address real-world industrial problems which may be part of larger OR projects associated with scientificl technological collaborations between the academy and the industry (e.g., JOLY et al., 2002). These technological partnerships have valuable advantages, such as shortening the learning curve of young researchers, since they establish tight collaboration with experienced engineers with profound knowledge of the business. It is worth noting that the learning curve in OR is typically long since it is built on the basis of accumulated experience in silico (i.e., computational) and in vivo (i.e., the real-world in which the system of interest is embedded). In other words, the problem is not just a mathematical one. Therefore, any action intended to shorten this long learning curve should be seriously considered at the educational level in the academy. The problems addressed can be of operational (e.g., supply-chain management) or strategic natures (e.g., the optimal design of refining schemes or logistic systems, refinery revamps, the 
optimal design of chemical reactors, the design of complex industrial automation solutions such as real-time optimizers, etc.).

On the other hand, an OR related Ph.D. program can [and should (OTTINO, 2011)] consider interdisciplinary research (e.g., JOLY and PINTO, 2006). In other words, we need to expand the set of the adjacent possible in chemical engineering. As Gus Aris (University of Minnesota) said: "That a graduate student should emerge with the title of 'Doctor of Philosophy' without the least contact with modes of thought outside his own field is in the highest degree deplorable..." (Gus Aris quoted in OTTINO, 2011). In this sense, an interesting possibility is to apply control and optimization engineering techniques in problems of the biological universe, which is currently the main focus of front-edge ChE research (see OTTINO, op cit.). Interdisciplinary collaboration is a crucial factor to guarantee the quality and the originality of high-profile scientific research as well as its practical applicability (JOLY et al., 2015b).

Since merging competencies and prior experiences, interdisciplinary collaboration may also shorten the time required for obtaining results. Complex thinking is a formidable subject to be addressed by postdoctoral researchers aiming at producing novel mathematical approaches for analysis, representation and solution of real-world systems which have been addressed in a simplified fashion (i.e., as complicated systems) in earlier phases of the scientific development. A representative example is the oil industry supply chain (SC). The management of SCs is currently performed through disaggregating the whole problem into well-defined interconnected subproblems according to a hierarchical decision-making framework (see JOLY, 2012). Emergent properties of the system are not taken into account when such conventional solution approaches are considered. Recognizing that emergent properties exist in engineering complex systems is the first obstacle to be overcome and we argue that solely those who have a solid experience in implementing OR in real-world settings are sensitive to this fact. "The problem was solved by itself" is a sentence that would not sound nonsensical for a habitué of a refinery planning and scheduling department and this is just an additional evidence that emergent properties are permanently acting on the aforementioned complex (open) system. An organicist viewpoint of the problem is now required. At the operational level, this educational model should gradually motivate the creation of a specialized, sustainable structure in which all actors are oriented to a common objective: producing innovative research.

\section{Conclusions}

In conclusion, we argue that learning OR (or in a more comprehensive sense: large-scale optimization) in $\mathrm{ChE}$ undergraduate courses is not only relevant per se. Actually, it should be understood as an intermediary, yet valuable educational step to enable $\mathrm{ChE}$ students to go beyond what has been conventionally attempted in front-edge $\mathrm{ChE}$ research. If, on the one hand, biology may represent the great professor for chemical engineers involved with such high-profile challenges as cited before, on the other, huge mathematical models may result. Not only computational intractability is at stake, but also the fidelity of the mathematical model with respect to the real-world process may be jeopardized; emergent properties can no longer be neglected. Adding more and more variables to model such complex systems is not the choice; new approaches are required. Moving from reductionism to an organicist view of such systems is a must for the chemical engineer of the $21^{\text {st }}$ century and a curricular challenge to contemporary $\mathrm{ChE}$ undergraduate courses. In this sense, OR may represent a high-performing catalyst to reach this educational target in the long-term.

\section{Note}

1 Abbreviations: ChE, chemical engineering; OR, Operations Research.

\section{References}

BERTALANFFY, Ludwig von. General Systems Theory, Foundations, Development, Applications. New York: George Braziller Inc., 1968. 
BIEGLER, L. T.; GROSSMANN, I. E.; WESTERBERG, A. W. Systematic Methods of Chemical Process Design, Prentice Hall,1997.

HU, S.; TOWLER, G.; ZHU, X. X. "Combine Molecular Modeling with Optimization to Stretch Refinery Operation". Industrial \& Engineering Chemistry Research, vol. 41, n. 4, 2002, pp. 825-841.

JOLY, M. "Corruption: the Shortcut to Disaster". Sustainable Production and Consumption, 2016 (accepted).

"Refinery Production Planning and Scheduling: the Refining Core Business". Brazilian Fournal of Chemical Engineering, vol. 29, n. 2, 2012, pp. 371-384.

JOLY, M.; MORIMOTO, A. H.; ONODA, K. A.; MIYAKE, M. Y.; LE ROUX, G. A. C. "An Exercise in Multiperiod Logistics Planning in the Downstream Oil Industry". Brazilian Fournal of Chemical Engineering, 2016 (in press).

JOLY, M.; MORO, L. F. L.; PINTO, J. M. "Planning and Scheduling for Petroleum Refineries Using Mathematical Programming". Brazilian fournal of Chemical Engineering, vol. 19, n. 2, 2002, pp. 207-228.

JOLY, M. \& ODLOAK, D. "Modeling Interleukin-2based Immunotherapy in AIDS Pathogenesis". Fournal of Theoretical Biology, vol. 335, out. 2013, pp. 57-78.

JOLY, M. \& PINTO, J. M. "Role of Mathematical Modeling on the Optimal Control of HIV-1 Pathogenesis". AIChE Fournal, vol. 52, n. 3, 2006, pp. 856-884.

JOLY, M.; PINTO, J. M.; RONDÓ, P. H. G.; RODRIGUES, R.; FERREIRA, J. L. P.; CAVALCANTI, J. S.; BRÍGIDO, L. F. M.; ODLOAK, D. "Combine Operations Research with Molecular Biology to Stretch Pharmacogenomics and Personalized Medicine - A Case Study on HIV/ AIDS. Computers and Chemical Engineering, vol. 80, 2015b, pp. 114-129.

JOLY, M.; ROCHA, R.; SOUSA, L. C. F.; TAKAHASHI, M. T.; MENDONÇA, P.N.; MORAES, L. A. M.; QUELHAS, A. D. "The Strategic Importance of Teaching Operations Research for Achieving High Performance in the Petroleum Refining Business". Education for Chemical Engineers, vol. 10, 2015a, pp. 1-19.
JOLY, M. \& RONDÓ, P. H. C. "The Future of Computational Biomedicine: Complex Systems Thinking". Mathematics and Computers in Simulation 2016 (in press; doi:10.1016/j.matcom.2015.06.010).

KAUFFMAN, Stuart. "Autonomous Agents, Selfconstructing Biospheres, and Science". Complexity, nov. 1996 , pp. $16-17$ (doi: 10.1002/(SICI) 10990526(199611/12)2:23.0.CO;2-L).

KRUGER, J. \& DUNNING, D. "Unskilled and Unaware of It: How Difficulties in Recognizing One's Own Incompetence Lead to Inflated Self-assessments". Fournal of Personality and Social Psychology, vol. 77, n. 6, 1999, pp. 1121-1134.

MENDEZ, C. A.; HENNING, G. P.; CERDA, J. "Optimal Scheduling of Batch Plants Satisfying Multiple Product Orders with Different Due-dates. Computers and Chemical Engineering, vol. 24, n. 9, 2000, pp. 2223-2245.

MOSSIO, M.; SABORIDO, G.; MORENO, A. "An Organizational Account of Biological Functions". British Fournal for the Philosophy of Science, vol. 60, 2009, pp. 813-841.

ORESKES, N.; SHRADER-FRECHETTE, K.; BELITZ, K. "Verification, Validation, and Confirmation of Numerical Models in the Earth Sciences". Science, vol. 263, 1994, pp. 641-646.

OTTINO, J. M. "Complex Systems". AIChE Fournal, vol. 49, n. 2, 2003, pp. 292-299.

OTTINO, J. M. "Chemical Engineering in a Complex World: Grand Challenges, Vast Opportunities". AIChE fournal, vol. 57, n. 7, 2011, pp. 1654-1668.

ROSENTHAL, R. E. GAMS - A User's Guide. Washington (DC): GAMS Development Corporation; 2010.

SYMONDS, G. H. Linear Programming: The Solution of Refinery Problems. New York: Esso Standard Oil Co., 1955.

ZHANG, N. \& VALLEUR, M. "Refinery Planning and Scheduling". In: RIAZI, M. R.; ESER, S.; DIEZ, J. L. P.; AGRAWAL, S. S. (edits.). Handbook of Petroleum Refining and Natural Gas Processing (Chapter 18). Conshohocken (PA): ASTM International; 2010.

Publicado em 11/11/2016. 